\title{
Evaluation of the Cyclooxygenase Inhibiting Effects of Six Major Cannabinoids Isolated from Cannabis sativa
}

\author{
Lucia Renee RuhaAK, ${ }^{*, a, b, \dagger}$ Jenny Felth,${ }^{a, \#}$ Pernilla Christina Karlsson, ${ }^{c}$ Joseph James Rafter ${ }^{c}$ \\ Robert VERPOORTE, ${ }^{b}$ and Lars BOHLIN ${ }^{a}$ \\ ${ }^{a}$ Division of Pharmacognosy, Department of Medicinal Chemistry, Biomedical Centre, Uppsala University; Box 574, SE- \\ 75123 Uppsala, Sweden: ${ }^{b}$ Division of Pharmacognosy, Section Metabolomics, Institute of Biology, Leiden University; \\ 2300 RA, Leiden, the Netherlands: and ${ }^{c}$ Department of Biosciences and Nutrition, Karolinska Institutet; Novum, S-141 86 \\ Huddinge, Sweden. Received December 22, 2010; accepted February 19, 2011; published online February 28, 2011
}

Cyclooxygenase enzymes (COX-1 and COX-2) catalyse the production of prostaglandins from arachidonic acid. Prostaglandins are important mediators in the inflammatory process and their production can be reduced by COX-inhibitors. Endocannabinoids, endogenous analogues of the plant derived cannabinoids, occur normally in the human body. The Endocannabinoids are structurally similar to arachidonic acid and have been suggested to interfere with the inflammatory process. They have also been shown to inhibit cancer cell proliferation. Antiinflammatory effects of cannabinoids and endocannabinoids have been observed, however the mode of action is not yet clarified. Anti-inflammatory activity (i.e., inhibition of COX-2) is proposed to play an important role in the development of colon cancer, which makes this subject interesting to study further. In the present work, the six cannabinoids tetrahydrocannabinol ( $\Delta^{9}$-THC), tetrahydrocannabinolic acid ( $\Delta^{9}$-THC-A), cannabidiol (CBD), cannabidiolic acid (CBDA), cannabigerol (CBG) and cannabigerolic acid (CBGA), isolated from Cannabis sativa, were evaluated for their effects on prostaglandin production. For this purpose an in vitro enzyme based COX1/COX-2 inhibition assay and a cell based prostaglandin production radioimmunoassay were used. Cannabinoids inhibited cyclooxygenase enzyme activity with $\mathrm{IC}_{50}$ values ranging from $1.7 \cdot 10^{-3}$ to $2.0 \cdot 10^{-4} \mathrm{M}$.

Key words cannabinoid; cyclooxygenase inhibition; prostaglandin production

Cyclooxygenase enzymes (COX enzymes) catalyse the production of prostaglandins, which are important mediators in the inflammatory process. To date, two isoforms of COX have been identified; a constitutively expressed enzyme, COX-1 and an inducible enzyme, COX-2, ${ }^{1,2)}$ of which the latter is induced by inflammatory stimuli. An important group of anti-inflammatory drugs is the Non-Steroid Anti Inflammatory Drugs (NSAIDs), of which aspirin and indomethacin are representatives. These compounds act by inhibiting the COX enzymes. The substrate for the prostaglandin production is arachidonic acid (Fig. 1), ${ }^{1)}$ an eicosanoid, which is produced on demand by phospholipase $\mathrm{A}_{2}$ from arachidonate, which is stored in the lipid bilayers of the cell wall. ${ }^{3)}$ In recent years, COX-2 overexpression has been associated with colon cancer development, and COX enzyme inhibition is studied as a potential target for cancer chemoprevention. ${ }^{4,5)}$

Other compounds in the eicosanoid group are the endocannabinoids. These endogenous compounds bind to cellular receptors, including the cannabinoid receptors, which are the molecular targets of the active principle in Cannabis sativa. The biological function of the endocannabinoids involves several regulatory agents, forming the endocannabinoid system (ECS) ${ }^{6}$ It has been reported that endocannabinoids also can function as substrates for the COX enzymes resulting in production of prostaglandin ethanolamides and prostaglandin glycerol esters. ${ }^{7,8)}$ Recently, the endogenous cannabinoid anandamide was shown to induce COX-2 dependent cell death in colon cancer cells. ${ }^{9}$

There are several structural (Fig. 1) and physiological similarities between human endocannabinoids and cannabinoids occurring in plant material. Structurally the 5-carbon side

\footnotetext{
${ }^{\dagger}$ Present address: Department of Chemistry, University of California at Davis, Davis, CA 95616, U.S.A.
}

chain in cannabinoids is present in the endocannabinoids as the last five carbons of the fatty acid chain, and the $\mathrm{C}-3 \mathrm{OH}$ might correspond to the polar hydroxyl end of the endocannabinoids. Furthermore, the relative distances between
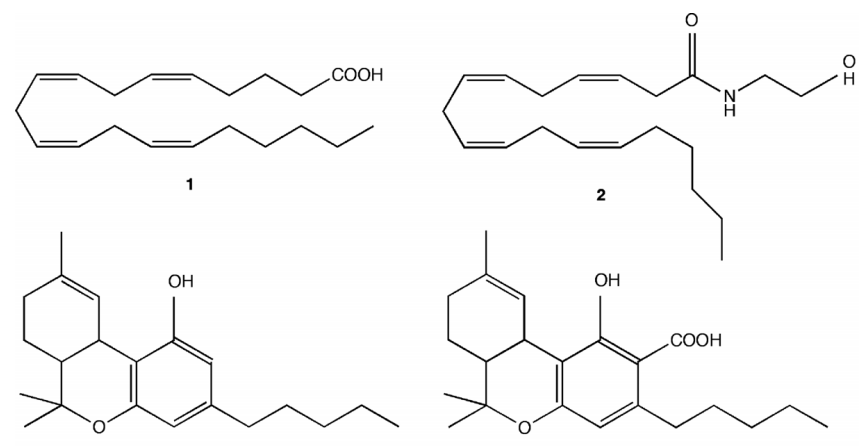

3
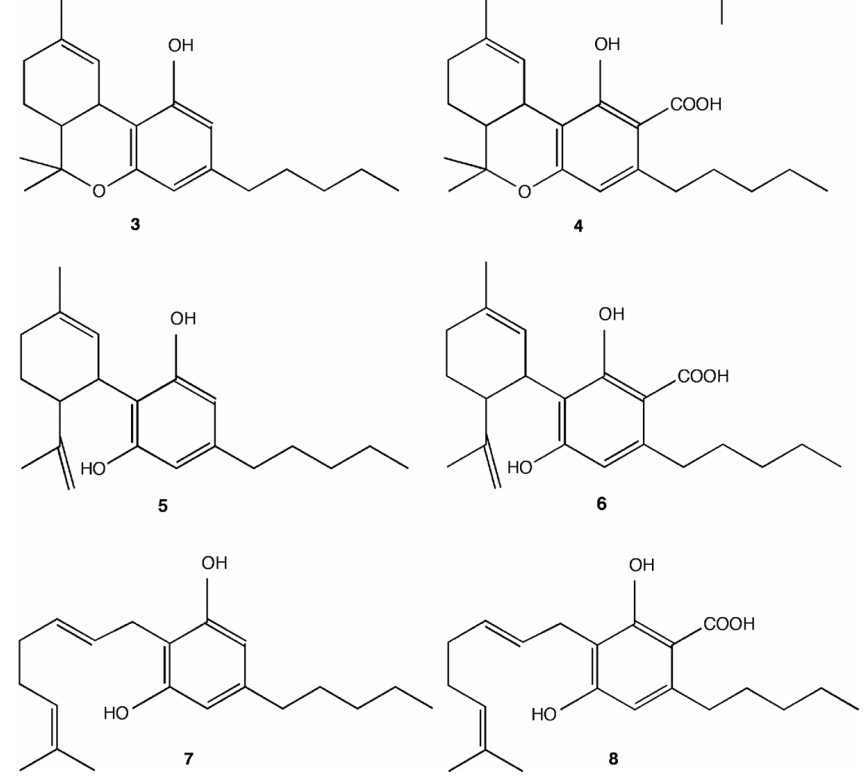

Fig. 1. Structural Formulas of the Endocannabinoid Anandamide (1) and the Endocannabinoid Precursor Arachidonic Acid (2) together with the Six Cannabinoids; $\Delta^{9}$-THC (3), $\Delta^{9}$-THCA-A (4), CBD (5), CBDA (6), CBG (7), CBGA (8) 
the groups are comparable due to the ring system in cannabinoids, which can be mimicked by the U-shaped endocannabinoids and their four double bonds. ${ }^{10)}$ Also physiologically there are similarities, since both cannabinoids and endocannabinoids bind to the cannabinoid receptors. ${ }^{11)}$ Endocannabinoids, such as anandamide, are derived from arachidonic acid and are structurally similar to this compound (Fig. 1).

Altogether, these similarities gave rise to the hypothesis that cannabinoids can affect the COX enzyme activity. Several studies have demonstrated anti-inflammatory activities in vivo and in vitro for various cannabinoid compounds, ${ }^{12-18)}$ which makes this hypothesis very plausible. Inhibiting effects on COX enzyme activity have also previously been observed for cannabidiol and cannabidiolic acid, ${ }^{17,19}$ ) and cannabinoids have potential to affect the potency of NSAIDs. ${ }^{20,21)}$ Furthermore, in recent years, it has been shown that the ECS can protect against colonic inflammation, ${ }^{6,22)}$ which is of interest in prevention of bowel disease and colorectal cancer. The cannabinoid receptors are suggested to be involved in the control of colonic inflammation, ${ }^{6,22)}$ however, the mode of action for the anti-inflammatory effects of cannabinoids is not yet clarified.

In the present study we evaluated the COX-mediated antiinflammatory properties of six different naturally occuring cannabinoids; tetrahydrocannabinol $\left(\Delta^{9}\right.$-THC), tetrahydrocannabinolic acid-A (THCA-A), cannabidiol (CBD), cannabidiolic acid (CBDA), cannabigerol (CBG) and cannabigerolic acid (CBGA) (Fig. 1). An enzyme-based in vitro COX inhibition assay was used to evaluate the effects on both COX-1 and COX-2 on enzyme-level, while a cell-based prostaglandin production assay was used to evaluate the effects on COX-2 at cellular level.

\section{MATERIALS AND METHODS}

Materials All solvents were purchased from Lab-Scan, Dublin, Ireland, and were of analytical grade. Scientific samples of cannabinoids $\left(\Delta^{9}-\mathrm{THC}\right.$, THCA-A, CBD, CBDA, $\mathrm{CBG}$ and CBGA) were provided by Prof. Robert Verpoorte and Dr. Arno Hazekamp, Leiden University, The Netherlands. The cannabinoids were isolated from Cannabis sativa and characterized and quantified using the chromatography and ${ }^{1} \mathrm{H}-\mathrm{NMR}$ methods as described by Hazekamp et al. ${ }^{23,24)}$ All cannabinoid samples were at least $92 \%$ pure.

COX-1 enzyme, purified from ram seminal vesicles and COX-2 enzyme, purified from sheep placental cotyledons, and the reference compound NS-398 ( $N$-[2-(cyclo-hexyloxy)-4-nitrophenyl]methanesulphonamide) were purchased from Cayman Chemical Co., Ann Arbor, MI, U.S.A. Hematin was obtained from ICN biomedicals Inc., Aurora, Ohio, U.S.A. Adrenalin was purchased from Apoteket AB, Göteborg, Sweden. Reduced gluthatione, indomethacine, unlabeled arachidonic acid, anti-prostaglandin $\mathrm{E}_{2}$, prostaglandin $\mathrm{E}_{2}$ standard, Bovine Serum Albumin, tumor necrosis factor (TNF)- $\alpha$ and charcoal were obtained from Sigma-Aldrich, St. Louis, MO, U.S.A. ${ }^{14}$ C-Arachidonic acid, [5,6,8,11,12,$\left.14,15(n)-{ }^{3} \mathrm{H}\right]$ Prostaglandin $\mathrm{E}_{2}$ and dextran molecular weight (mw) 70000 was purchased from Amersham Pharmacia, Stockholm, Sweden, while silica gel 60, particle size 0.063 $2 \mathrm{~mm}$ was obtained from Merck, Darmstadt, Germany. Dul- becco's modified Eagle's medium (DMEM)-high glucose and trypsin-ethylenediaminetetraacetic acid (EDTA) were obtained from Invitrogen, Taastrup, Denmark.

Cell Culture The human colon adenocarcinoma cell line HT29, was cultured in monolayer in DMEM (Dulbecco's modified Eagle medium supplemented with $10 \%$ fetal bovine serum (FBS), $2 \mathrm{mM}$ L-glutamine, and 1\% penicillin/streptomycin) at $37^{\circ} \mathrm{C}$ and $5 \% \mathrm{CO}_{2}$. All experiments were performed with $60-80 \%$ confluent cells and $0.1 \%$ DMEM $(0.1 \%$ FBS $)$. Pure compounds were dissolved in ethanol and diluted in $0.1 \%$ DMEM (with the final concentration in the cell cultures being maximum $0.25 \%$ ethanol).

Enzyme-Based Inhibition Assay The assay followed the original method described by White and Glassman, ${ }^{25}$ ) with modifications as described by Noreen et $a .^{26)}$ The assay described below was used for both COX-1 and COX-2 enzymes. In short, $20 \mu \mathrm{l}$ of each sample was dispensed in a 96well plate. All samples were dissolved in $20 \%$ dimethyl sulfoxide (DMSO) in TRIS buffer. To determine minimal and maximal activity of the enzyme, 20\% DMSO in TRIS buffer was used as the sample. Total inhibition of the enzyme in the minimum wells was reached by addition of $10 \mu \mathrm{l}$ of $2 \mathrm{M} \mathrm{HCl}$ to the wells before the enzyme was added. Cofactors were dissolved in TRIS buffer to concentrations of $1.27 \mathrm{mg} / \mathrm{ml}$ hematin, $6.50 \mathrm{mg} / \mathrm{ml}$ adrenalin and $1.50 \mathrm{mg} / \mathrm{ml}$ gluthatione, giving final concentrations in the wells of $1.3 \mu \mathrm{g} / \mathrm{ml}, 1.3$ $\mathrm{mg} / \mathrm{ml}$ and $0.3 \mathrm{mg} / \mathrm{ml}$ respectively. COX enzyme was mixed with the co-factors, pre-incubated and activated on ice for $5 \mathrm{~min}$. Sixty microliters of enzyme-cofactor solution was added to the sample in the wells, and the plate was incubated for $10 \mathrm{~min}$ on ice. The activity of the enzyme in the wells was $6 \mathrm{U}(\mathrm{COX}-1)$ or $3 \mathrm{U}(\mathrm{COX}-2)$. Twenty microliters of ${ }^{14} \mathrm{C}$ arachidonic acid $\left({ }^{14} \mathrm{C}\right.$-AA) solution was dispensed in each well and to start the enzymatic reaction, the plate was incubated in a $37^{\circ} \mathrm{C}$ waterbath for $15 \mathrm{~min}(\mathrm{COX}-1)$ or $3 \mathrm{~min}$ (COX-2). The reaction was stopped by addition of $10 \mu \mathrm{l}$ of $\mathrm{HCl}(2 \mathrm{M})$. To separate the non-converted ${ }^{14} \mathrm{C}$-AA from the ${ }^{14} \mathrm{C}$-labeled prostaglandins, column chromatography (Silica gel 60, particle size $0.063-2 \mathrm{~mm}$ ) was used. The columns were equilibrated using $2 \mathrm{ml}$ of eluent, consisting of heptane : ethyl acetate : acetic acid $(70: 30: 1)$, thereafter the samples were applied, and the non-converted AA was eluted using $4 \mathrm{ml}$ of the same eluent. The prostaglandins were then eluted using $3 \mathrm{ml}$ of a second eluent, consisting of dioxane: methanol $(85: 15)$. Scintillation fluid was added to the samples, and the amount of radioactively labeled prostaglandin in the samples was determined using a Packard scintillation spectrometer. Percent inhibition values were calculated and $\mathrm{IC}_{50}$-values were obtained by applying the nonlinear regression analysis tool of Graph Pad Prism (GraphPad Software Inc., CA, U.S.A.).

Prostaglandin $\mathrm{E}_{2}\left(\mathrm{PGE}_{2}\right)$ Production in HT29 Cells $\mathrm{PGE}_{2}$ is a major product produced by $\mathrm{COX}$ from arachidonic acid and is often used to estimate COX activity in cells. The method used is a standard procedure for measuring $\mathrm{PGE}_{2}$ production in cells, and has previously been described in detail. ${ }^{27-29)}$ In brief, HT29 cells were seeded out at a concentration of $3.30 \times 10^{5}$ cells/well. At day $2,100 \mu \mathrm{M}$ aspirin was added to the wells to prevent activation of COX-1. At day 3, the cells were incubated with TNF- $\alpha(50 \mathrm{ng} / \mathrm{ml})$ and cannabinoid samples $(12.5$ or $25 \mu \mathrm{M})$ for $5 \mathrm{~h}$, thereafter the test solu- 
tion was replaced with medium containing $100 \mu \mathrm{mol} / 1$ arachidonic acid (Sigma) and the cells were incubated for $1 \mathrm{~h}$. The concentration of released prostaglandin $\mathrm{E}_{2}\left(\mathrm{PGE}_{2}\right)$ was quantified using radio immuno-assay (RIA), according to the protocol supplied by Sigma Chemical Co., using $\left[{ }^{3} \mathrm{H}\right] \mathrm{PGE}_{2}$ and polyclonal antiserum to $\mathrm{PGE}_{2}$ (Sigma). The amount of prostaglandins in each sample was detected using a scintillation counter, and expressed as the percentage inhibition of the TNF- $\alpha$ treated cells. Each cannabinoid was tested at least twice in the cell system and later analyzed in duplicate in the RIA. The results were expressed as the percentage inhibition of the TNF- $\alpha$ treated cells. In all experiments untreated cells were included as controls, and the selective COX-2 inhibitor NS398 was used as a reference compound for comparison of inhibiting activity.

Prior to the PGE2 experiments, all cannabinoid samples were tested for cytotoxicity in the AlamarBlue ${ }^{\mathrm{TM}}$ assay to ensure that potential COX-2 inhibitory effects were not due to cell death. ${ }^{30,31)}$ A cell survival of approximately $70 \%$ was considered as acceptable for studying the prostaglandin production. Cannabinoid concentrations causing cell death (i.e., cell survival $<70 \%$ ) were excluded from the $\mathrm{PGE}_{2}$ production experiments.

\section{RESULTS}

Enzyme-Based Inhibition Assay The inhibitory effects of six cannabinoids on the cyclooxygenase enzyme activity was evaluated by an in vitro $\mathrm{COX}$ enzyme inhibition assay. $\Delta^{9}$-THC, $\Delta^{9}$-THCA-A, CBD, CBDA, CBG and CBGA were screened for their ability to inhibit COX-1 and COX-2 at a concentration of $100 \mathrm{mg} / \mathrm{ml}$ (approximately $3 \cdot 10^{-4} \mathrm{M}$ ), since higher concentrations were assumed to be irrelevant. In this screening, an enzyme inhibition of $\geq 30 \%$ was considered as sufficient to be relevant, and was set as a cutoff limit for compounds to investigate further. $\Delta^{9}$-THCA-A, CBDA, CBG and CBGA showed more than $30 \%$ inhibition on COX-1 (Fig. 2). The concentration-dependent activity (i.e. inhibition of COX-1) for these compounds was further evaluated at concentrations ranging from $3.18 \cdot 10^{-3}$ to $2.78 \cdot 10^{-5} \mathrm{M}$, as

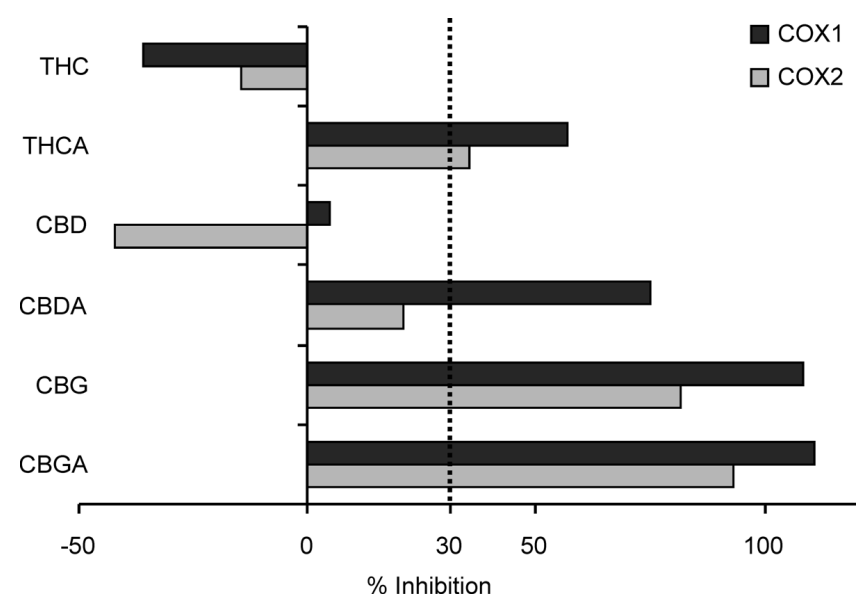

Fig. 2. Screening of Six Cannabinoids for Their Potential to Inhibit COX1 and COX-2 Enzymes

All cannabinoids were screened at concentrations of $100 \mu \mathrm{g} / \mathrm{ml}$. To justify further analysis, a cut off value of at least $30 \%$ inhibition was used, represented by the black dotted line. presented by concentration-effect graphs (Fig. 3A). The $\mathrm{IC}_{50}$-values are presented in Table 1 . The $\mathrm{IC}_{50}$-value of the reference compound indomethacin was within acceptable limits of the value reported previously for this COX-1 assay $\left(1.4 \cdot 10^{-6} \mathrm{M}\right){ }^{26)}$ confirming that the assay was successful.

When screened for COX-2 enzyme inhibiting activity $\Delta^{9}$ THCA-A, CBG and CBGA showed more than 30\% inhibition. Interestingly, $\mathrm{CBDA}$, which was recently reported to selectively inhibit COX-2, ${ }^{19}$ ) did not reach the $30 \%$ inhibition threshold (Fig. 2), and was therefore not considered in our further COX-2 inhibition studies. The inhibition of $\Delta^{9}$ THCA-A, CBG and CBGA was measured at concentrations ranging from $3.18 \cdot 10^{-3}$ to $2.78 \cdot 10^{-5} \mathrm{M}$, as represented by the concentration-effect graphs (Fig. $3 \mathrm{~B}$ ) with $\mathrm{IC}_{50}$ values presented in Table 1. The $\mathrm{IC}_{50}$ value of the reference compound indomethacin was within acceptable limits of the value previously reported for this COX-2 assay $\left(1.64 \cdot 10^{-6}\right.$ M), ${ }^{26)}$ confirming that the assay results were reliable.

Complementary to the enzyme-inhibition assay, the effects

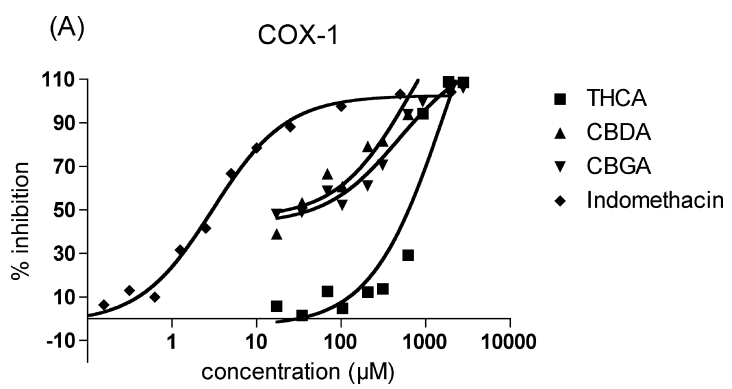

(B)

\section{coX-2}

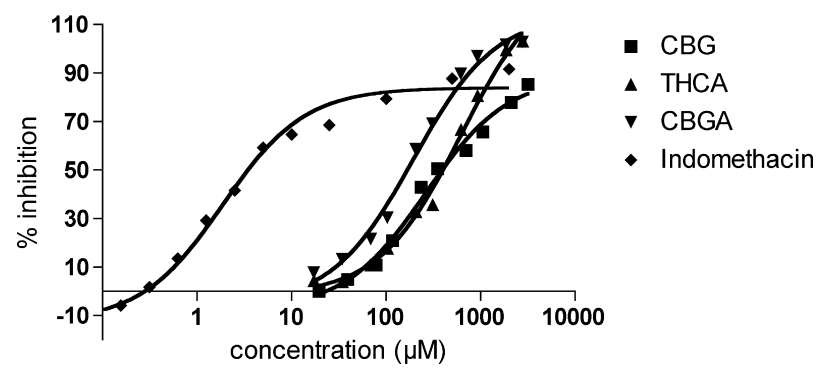

Fig. 3. (A) Graphs Representing the COX-1 Inhibition of $\Delta^{9}-\mathrm{THCA}-\mathrm{A}$, CBDA, CBGA and Indomethacin in the Enzyme Based Assay

For each datapoint $n=3$.

(B) Graphs Representing the COX-2 Inhibiton of $\Delta^{9}-\mathrm{THCA}-\mathrm{A}, \mathrm{CBG}$, CBGA and Indomethacin in the Enzyme Based Assay

For each datapoint $n=3$.

Table 1. COX Inhibition $\mathrm{IC}_{50}$-Values Determined for $\Delta^{9}$-THCA-A, CBG, CBGA and Indomethacin Using an Enzyme Based in Vitro Assay

\begin{tabular}{lcc}
\hline \hline \multirow{2}{*}{ Compound } & \multicolumn{2}{c}{$\mathrm{IC}_{50}(\mathrm{M})$} \\
\cline { 2 - 3 } & $\mathrm{COX}-1$ & $\mathrm{COX}-2$ \\
\hline$\Delta^{9}$-THCA-A & $1.7 \cdot 10^{-3}$ & $6.3 \cdot 10^{-4}$ \\
CBDA & $4.7 \cdot 10^{-4}$ & $\mathrm{~N} . \mathrm{D}^{a}$ \\
CBG & $\mathrm{N} . \mathrm{D}^{a}$ & $2.7 \cdot 10^{-4}$ \\
CBGA & $4.6 \cdot 10^{-4}$ & $2.0 \cdot 10^{-4}$ \\
Indomethacin & $3.1 \cdot 10^{-6}$ & $9.3 \cdot 10^{-5}$ \\
\hline
\end{tabular}

a) N.D., not determined. 


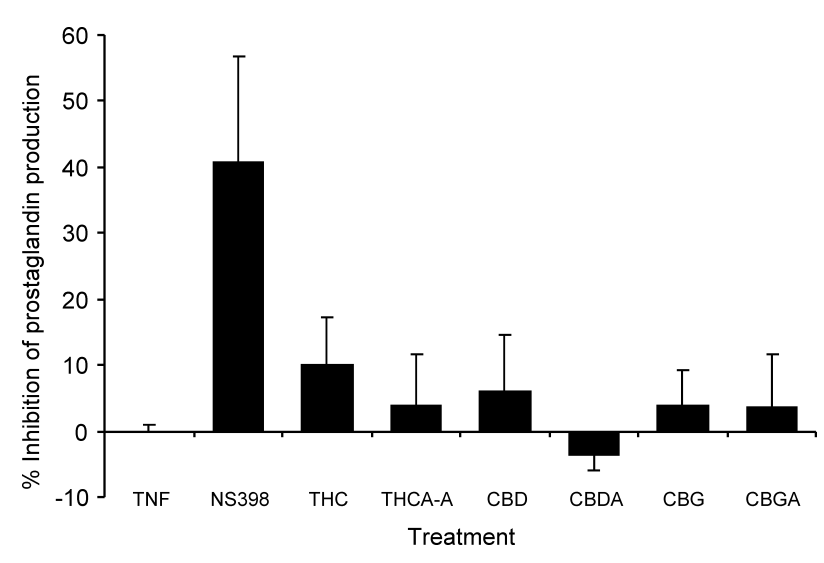

Fig. 4. Decrease in Prostaglandin Production in TNF- $\alpha$ Stimulated HT29 Cells

The prostaglandin production inhibitor NS398 was used as a reference compound. Error bars represent S.D.

of cannabinoids on prostaglandin production were examined in a cell based assay. Six different cannabinoids were tested for their ability to decrease prostaglandin production in TNF$\alpha$ stimulated HT29 cells. Prior to measuring the prostaglandin production, the effects of cannabinoids on cell survival were investigated, to make sure that the effects were not due to cell death. A cell survival of approximately $70 \%$ was considered as acceptable for studying the prostaglandin production, and the observed effects on the $\mathrm{PGE}_{2}$ production are very unlikely to be explained by cell death. Both apoptosis and necrosis make the cells detach from the plate surface. No such signs were observed. $\Delta^{9}-\mathrm{THC}, \mathrm{CBD}, \mathrm{CBDA}$ and $\mathrm{CBG}$ were tested at concentrations of $2.5 \cdot 10^{-5} \mathrm{M}$, whereas $\Delta^{9}$ THCA-A and CBGA were tested at a concentration of $6.25 \cdot 10^{-5} \mathrm{M}$. However, higher concentrations of cannabinoids caused a high cytotoxicity and could not be used in the experiments. The results, as presented in Fig. 4, showed that $\Delta^{9}$-THC, $\Delta^{9}$-THCA-A, CBD, CBG and CBGA inhibited prostaglandin production, however the level of inhibition was low $(<10 \%)$. CBDA, on the other hand seemed to stimulate the prostaglandin production (Fig. 4).

\section{DISCUSSION}

Cannabinoids have been shown to possess anti-inflammatory effects, ${ }^{12-18)}$ but the mechanism of action is not yet known. COX enzyme inhibiting activity has previously been observed for CBD and CBDA. ${ }^{17,19)}$ Overexpression of COX2 has in recent years also been associated with colon cancer development, ${ }^{5)}$ and COX-2 enzyme inhibition is regarded as a potential target for cancer chemoprevention. ${ }^{4)}$ Interestingly, endocannabinoid levels are elevated in colon cancer tissue, and they also inhibit cancer cell proliferation by acting at cannabinoid receptors. ${ }^{32)}$ Recently, it has also been shown that the ECS can protect against colonic inflammation, ${ }^{6,22)}$ which is of interest in prevention of bowel disease and colorectal cancer. Additionally, cannabinoids have been shown to affect the potency of NSAIDs, ${ }^{20,21)}$ potentially via modulation of the COX pathway.

In the present study, six major cannabinoids isolated from plant material modulated the activity of COX enzymes, with $\mathrm{IC}_{50}$ values ranging from $1.7 \cdot 10^{-3}$ to $2.0 \cdot 10^{-4} \mathrm{M}$. None of the cannabinoids showed high COX selectivity except from CBDA, which only inhibited COX-1. This finding is contradictory to previously reported results by Takeda et al., where CBDA was found to be a selective COX-2 inhibitor in an enzyme inhibition assay using purified COX enzymes. ${ }^{19)}$ These inconsistencies might be caused by differences in the detection method. In the present study radioactively labeled prostaglandin was measured, while Takeda et al. measured the oxidation of TMPD spectrophotometrically. Alternatively, as the cannabinoids used in the studies were purified from plant material, different impurities in the samples could cause different results. Further studies, preferably in human cell lines, are needed to validate the COX inhibition by cannabinoids.

In the screening, it was observed that $\Delta^{9}$-THC showed stimulation in a dose-related matter (between $3.18 \cdot 10^{-4}$ and $3.18 \cdot 10^{-5} \mathrm{M}$ ) both in the COX-1 inhibition assay and the COX-2 inhibition assay (data not shown). However, the COX-inhibition assay is not designed to quantify COX enzyme activation, and hence no definitive conclusions can be drawn from these findings.

Interestingly, CBD and $\Delta^{9}$-THC showed low activity in the in vitro assay of the COX-enzymes in comparison with the other cannabinoids tested. The COX inhibition assay is an in vitro assay where purified COX enzyme (from ram seminal vesicles and sheep placental cotyledons, respectively) is used. This assay is far from the human in vivo conditions. Therefore, we complementarily used human colon cancer cells to investigate if the prostaglandin production would be inhibited also in living cells. The inhibition of prostaglandin production in cancer cells is of great interest, since the inflammatory process is believed to be of importance for colon carcinogenesis. ${ }^{33)}$ As shown in Fig. 4, the results (e.g. inhibition of $\mathrm{PGE}_{2}$ production) from the cell-based assay were similar for all cannabinoids. All compounds tested inhibited the production of $\mathrm{PGE}_{2}$ only slightly. An experiment with higher concentrations might give more clear results. However, higher concentrations of the cannabinoids were cytotoxic, causing detachment of cells and signs of cell death, and such experiments were not possible to perform using this cellbased assay.

The cannabinoids are known to be involved in the immune system via the $\mathrm{CB}_{2}$ receptor. The binding constants $K_{\mathrm{i}}$ for $\Delta^{9}$-THC interacting with the $\mathrm{CB}_{1}$ and $\mathrm{CB}_{2}$ receptors are $8.0 \cdot 10^{-5} \mathrm{M}$ and $3.2 \cdot 10^{-5} \mathrm{M}$ respectively. ${ }^{34)}$ These binding constants are in the same range as the $\mathrm{IC}_{50}$ values we found for the COX-inhibition by cannabinoids. This might indicate a possibility of physiologically important effects of the COXinhibiting cannabinoids via interaction with the COX-enzymes. Further in vitro studies are required to prove such effects, but the present study shows that several of the major cannabinoids may also affect other receptors than $\mathrm{CB}_{1}$ and $\mathrm{CB}_{2}$. Interestingly, a recent report, linking COX-2 inhibition to increased endocannabinoid levels, suggests the ECS and the COX-mediated prostaglandin pathway to be closely connected. ${ }^{35)}$

In conclusion, it is clear that cannabinoids inhibit COXenzymes, but in a higher concentration range, as compared to anti-inflammatory drugs (i.e. indomethacin). The obvious contradiction regarding the selectivity for CBDA, as compared to the previous report by Takeda et al., ${ }^{19)}$ is interesting 
and should be object for further investigation. Additional studies will also be needed to conclude the relevance of the COX-inhibitory effects in relation to other anti-inflammatory activities mediated by cannabinoids. As evident from recent reports, the ECS plays an important role in the human body. Interestingly, colonic inflammation can be controlled via the ECS, and plant-derived cannabinoids may have a potential to be used as future therapeutic agents.

Acknowledgements This work was financially supported by Grants from the Agricultural Sciences and Spatial Planning (FORMAS) and European University Consortium for Pharmaceutical Research (ULLA). The authors also want to thank Dr. Ulrika Huss Melin for helpful discussion and Dr. Arno Hazekamp for providing purified cannabinoid samples.

\section{REFERENCES}

1) Chandrasekharan N. V., Simmons D. L., Genome Biol., 5, 241 (2004).

2) Simmons D. L., Botting R. M., Hla T., Pharmacol. Rev., 56, 387-437 (2004).

3) Leslie C. C., Biochem. Cell Biol., 82, 1-17 (2004).

4) Ruegg C., Zaric J., Stupp R., Ann. Med., 35, 476-487 (2003).

5) Zha S., Yegnasubramanian V., Nelson W. G., Isaacs W. B., De Marzo A. M., Cancer Lett., 215, 1-20 (2004).

6) Maccarrone M., Gasperi V., Catani M. V., Diep T. A., Dainese E., Hansen H. S., Avigliano L., Annu. Rev. Nutr., 30, $423-440$ (2010).

7) Kozak K. R., Rowlinson S. W., Marnett L. J., J. Biol. Chem., 275, $33744-33749$ (2000).

8) Yu M., Ives D., Ramesha C. S., J. Biol. Chem., 272, 21181-21186 (1997).

9) Patsos H. A., Greenhough A., Hicks D. J., Al Kharusi M., Collard T. J., Lane J. D., Paraskeva C., Williams A. C., Int. J. Oncol., 37, 187-193 (2010).

10) Tong W., Collantes E. R., Welsh W. J., Berglund B. A., Howlett A. C., J. Med. Chem., 41, 4207-4215 (1998).

11) Martin B. R., Jefferson R. G., Winckler R., Wiley J. L., Thomas B. F., Crocker P. J., Williams W., Razdan R. K., Eur. J. Pharmacol., 435, 35-42 (2002).

12) Malfait A. M., Gallily R., Sumariwalla P. F., Malik A. S., Andreakos E., Mechoulam R., Feldmann M., Proc. Natl. Acad. Sci. U.S.A., 97, 9561-9566 (2000).

13) Sofia R. D., Knobloch L. C., Vassar H. B., Res. Commun. Chem. Pathol. Pharmacol., 6, 909—918 (1973).
14) Sofia R. D., Nalepa S. D., Harakal J. J., Vassar H. B., J. Pharmacol. Exp. Ther., 186, 646-655 (1973).

15) Sofia R. D., Nalepa S. D., Vassar H. B., Knobloch L. C., Life Sci., 15, $251-260$ (1974).

16) Wirth P. W., Watson E. S., ElSohly M., Turner C. E., Murphy J. C., Life Sci., 26, 1991-1995 (1980).

17) Costa B., Colleoni M., Conti S., Parolaro D., Franke C., Trovato A. E., Giagnoni G., Naunyn Schmiedebergs Arch. Pharmacol., 369, 294 299 (2004).

18) Burstein S. H., Zurier R. B., AAPS J., 11, 109-119 (2009).

19) Takeda S., Misawa K., Yamamoto I., Watanabe K., Drug Metab. Dispos., 36, 1917-1921 (2008).

20) Anikwue R., Huffman J. W., Martin Z. L., Welch S. P., J. Pharmacol. Exp. Ther, 303, 340-346 (2002).

21) Guindon J., De Lean A., Beaulieu P., Pain, 121, 85-93 (2006).

22) Massa F., Marsicano G., Hermann H., Cannich A., Monory K., Cravatt B. F., Ferri G. L., Sibaev A., Storr M., Lutz B., J. Clin. Invest., 113, 1202-1209 (2004)

23) Hazekamp A., Simons, R., Peltenburg-Looman, A., Sengers, M., Van Zweden, P., Verpoorte, R., J. Liq. Chromatogr. Relat. Technol., 27, 2421-2439 (2004)

24) Hazekamp A., Choi Y. H., Verpoorte R., Chem. Pharm. Bull., 52, $718-721$ (2004).

25) White H. L., Glassman A. T., Prostaglandins, 7, 123-129 (1974).

26) Noreen Y., Ringbom T., Perera P., Danielson H., Bohlin L., J. Nat. Prod., 61, 2-7 (1998).

27) Calviello G., Di Nicuolo F., Gragnoli S., Piccioni E., Serini S., Maggiano N., Tringali G., Navarra P., Ranelletti F. O., Palozza P., Carcinogenesis, 25, 2303-2310 (2004).

28) Pettersson J., Karlsson P. C., Goransson U., Rafter J. J., Bohlin L., Biol. Pharm. Bull., 31, 534-537 (2008).

29) Yamada M., Niki H., Yamashita M., Mue S., Ohuchi K., J. Pharmacol. Exp. Ther, 281, 1005-1012 (1997).

30) Klinder A., Gietl E., Hughes R., Jonkers N., Karlsson P., McGlyn H., Pistoli S., Tuohy K., Rafter J., Rowland I. R., van Loo J., L. P.-Z. B., Int. J. Cancer Prev., 1, 19-32 (2004).

31) O’Brien J., Wilson I., Orton T., Pognan F., Eur. J. Biochem., 267, $5421-5426$ (2000).

32) Ligresti A., Bisogno T., Matias I., De Petrocellis L., Cascio M. G., Cosenza V., D’Argenio G., Scaglione G., Bifulco M., Sorrentini I., Di Marzo V., Gastroenterology, 125, 677-687 (2003).

33) Terzic J., Grivennikov S., Karin E., Karin M., Gastroenterology, 138 , 2101-2114 e2105 (2010).

34) Rhee M. H., Vogel Z., Barg J., Bayewitch M., Levy R., Hanus L., Breuer A., Mechoulam R., J. Med. Chem., 40, 3228-3233 (1997).

35) Telleria-Diaz A., Schmidt M., Kreusch S., Neubert A. K., Schache F., Vazquez E., Vanegas H., Schaible H. G., Ebersberger A., Pain, 148, $26-35$ (2010). 